\title{
Religious and Ethnic Identities: The Romaniote (Greek) Jews in the US
}

\section{Nicholas Alexiou*}

This paper explores key aspects of the immigration history and experience of Romaniote (Greek) Jews to the United States. The paper consists of an empirical study of a selected number of Romaniote Jews in New York, measuring aspects of ethnic identity, attachment to the community, and level of assimilation. Finally, the study documents that historically the immigration pattern of the Greek Jews is similar to that of the Christian Greeks, and in this respect, their immigration experience needs to be considered also as part of the overall Greek mass immigration in the United States. [Article copies available for a fee from The Transformative Studies Institute. E-mail address: journal@transformativestudies.org

Website: http://www.transformativestudies.org (C2009 by The Transformative Studies Institute. All rights reserved.]

KEYWORDS: Ethnicity, Immigration, Religion, Romaniote (Greek) Jews.

\section{INTRODUCTION}

Within the American sociological tradition there is a general understanding that the United States continues to be a diverse society, composed of groups and individuals from different ethnic, racial, and cultural back-

\footnotetext{
* Nicholas Alexiou, Ph.D., is a Chancellor's Lecturer at Queens College, where he teaches at the Department of Sociology and at the Center for Byzantine and Modern Greek Studies. He has published on ethnicity and immigration in various scholarly disciplines, including sociology, and diaspora and cultural studies. In 2007, he received the President's Award for Excellence in Teaching. Also, he is the author of several poetry collections, and selections of his work have been appeared in anthologies of Greek American poetry. Address correspondence to: Nicholas Alexiou, Queens College, Department of Sociology and Center for Byzantine and Modern Greek Studies, 65-30 Kissena Blvd, Flushing, New York 11367; tel: (718) 997-2826; e-mail: Nicholas.Alexiou@qc.cuny.edu.
} 